Access this article online

Quick Response Code:

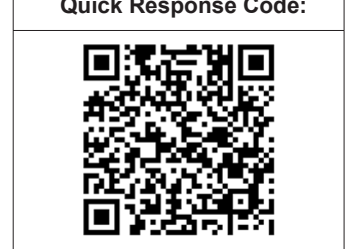

Website:

www.jponline.org

DOI:

10.4103/JLP.JLP_93_18
Department of Community Medicine, Dr. Baba Saheb Ambedkar Medical College and Hospital, New Delhi, India

Address for correspondence:

Dr. Vikas Kumar, Department of Community Medicine, Dr. Baba Saheb Ambedkar Medical College and Hospital, Rohini, New Delhi - 110 085, India. E-mail: drvikaspsm@ gmail.com

Submission: 12-07-2018 Accepted: 24-09-2018

\section{Assessment of knowledge, attitude, and practices toward prevention of hepatitis B infection among medical students in a high-risk setting of a newly established medical institution}

\author{
Akanksha Rathi, Vikas Kumar, Jitendra Majhi, Shalini Jain, Panna Lal, Satyavir Singh
}

\title{
Abstract:
}

BACKGROUND: India is in the intermediate hepatitis B virus endemicity zone with hepatitis B surface antigen prevalence among the general population ranges from $2 \%$ to $8 \%$. Among health-care workers, seroprevalence is two to four times higher than that of the general population.

AIM: The aim of the study was done to assess the knowledge, attitude, and practices (KAPs) of medical students regarding hepatitis $B$.

MATERIALS AND METHODS: This is a cross-sectional study that was conducted from March to April 2018. Students were invited to the department on specified dates for awareness and immunization against hepatitis B. Their KAP was assessed with the help of a self-administered questionnaire.

RESULTS: With a response rate of $81.3 \%$, a total of 161 students participated in the study out of 198. Out of the 161 study participants, only $13(8 \%)$ students had received a completed course of hepatitis $B$ vaccination in the past, $30(18.7 \%)$ students had a history of inability to complete the three doses of hepatitis B vaccination, and the rest 118 (73.3\%) students were never immunized against hepatitis $\mathrm{B}$. The knowledge about the risk of acquiring the disease at the hospital or high-risk setting was present in less than half of the students. The average knowledge score was 10.63 out of 16 and average healthy practice score was 2.94 out of 4 . On applying Pearson correlation test, it was found that there was a positive correlation of knowledge and practices of the students $(P=0.012)$, implying that better knowledge of the disease has a positive effect on the practices exercised by an individual.

CONCLUSION: Newly enrolled students and other individuals attached to a high-risk setting such as a medical institution should be screened for immunization status during initial medical examination as the number of unimmunized persons, especially against hepatitis B is high.

Key words:

Hepatitis screening, hepatitis $B$, high risk, knowledge, attitude, and practices, medical students

\section{Introduction}

T Tepatitis B infection is an ancient disease 1 from the times of Bronze Age ${ }^{[1]}$ which had been suspected as an agent of infection in the 50s which was later reported first as Australian antigen in the $60 s,{ }^{[2]}$ and subsequently discovered under the electron

This is an open access journal, and articles are distributed under the terms of the Creative Commons Attribution-NonCommercial-ShareAlike 4.0 License, which allows others to remix, tweak, and build upon the work non-commercially, as long as appropriate credit is given and the new creations are licensed under the identical terms.

For reprints contact: reprints@medknow.com microscope in the 70s. ${ }^{[3]}$ Vaccination for hepatitis B was introduced in the $80 \mathrm{~s} .{ }^{[4]}$

Hepatitis B is a major public health problem as one-third of the world population is infected with hepatitis $B$ virus $(\mathrm{HBV}){ }^{[5,6]}$ Based on the prevalence of hepatitis B surface antigen (HBsAg), different areas of the world are classified as

How to cite this article: Rathi A, Kumar V, Majhi J, Jain S, Lal P, Singh S. Assessment of knowledge, attitude, and practices toward prevention of hepatitis $B$ infection among medical students in a high-risk setting of a newly established medical institution. J Lab Physicians 2018;10:374-9. 
having high $(\geq 8 \%)$, intermediate $(2 \%-7 \%)$, or low $(<2 \%)$ HBV endemicity. ${ }^{[7]}$ India is in the intermediate HBV endemicity zone (HBsAg prevalence among the general population ranges from $2 \%$ to $8 \%$ ) with 50 million cases which makes it the second largest global pool of chronic HBV infection. ${ }^{[8,9]}$

Among the health-care workers (HCWs), seroprevalence is two to four times higher than that of the general population. ${ }^{[10]}$ They remain at risk of acquiring HBV infection mainly through percutaneous or mucosal exposure to infected blood or body fluids. ${ }^{[11]}$ India contributes to $25 \%-30 \%$ of the global injection load, as injections are overprescribed, often to satisfy the whims of the general population which thinks injections are more efficacious than oral route, and unsafe injection practices are common. ${ }^{[12-14]}$ A 2-year surveillance study from India even reported that 59/255 (23.13\%) of HCW had needlestick exposure. ${ }^{[15]}$ This high prevalence of infection transmission can be largely attributed to careless handling of infectious material, inadequate sterilization of medical equipment, and improper waste disposal. ${ }^{[16,17]}$ The risk might be even greater if the HCW is a trainee, intern, or just a student as they have lack of experience, insufficient training, or plain carelessness. ${ }^{[18,19]}$

Hepatitis B infection transmission chain can be interrupted through vaccination, using of safety precautions while handling infectious material, proper sterilization of medical equipment, and legit waste handling. ${ }^{[20-23]}$ However, the studies have indicated that there is a clear gap of knowledge among trainees of health profession toward the risks of occupational exposure to HBV infection. ${ }^{[24,25]}$

In India, hepatitis B vaccine was launched in 2003 along with a birth dose within $24 \mathrm{~h}$ which was expanded to the whole country in 2008. ${ }^{[26]}$ Complete vaccination confers immunity for at least 20 years. Hepatitis B is a DNA virus and is much stable than other RNA virus such as influenza and no mutation has been reported. Thus, hepatitis B can be eliminated if coverage of vaccination is expanded across all ages. Most of the Indian subcontinent population born before 2008 has not received hepatitis $B$ vaccination except few who might have availed from the private sector, currently, the proportion of population engaged in high-risk environments such as the health-care sector hails from this cohort of population. In a resource-limited settings of a low- and middle-income country like India, The current World Health Organization (WHO) guidelines advocate to implement hepatitis B vaccination coverage programs to be tailored within the existing facilities and platforms of medical institutions, national programs, workplaces, government schools, offices, etc., for opportunistic vaccination drives. ${ }^{[27,28]}$
The study institute is a newly established Medical Institution under the Government of National Capital Region of Delhi since 3 years, wherein the department of community medicine organized a vaccination program for hepatitis B for the newly admitted MBBS students with a goal of conferring immunity against hepatitis B infection before the students are exposed to high-risk environments later during their internships and career. This study has been conducted in congruence of the hepatitis B vaccination program to shed some light on the knowledge, attitude, and practices (KAPs) of medical students toward occupational exposure to this disease.

\section{Materials and Methods}

This is a cross-sectional study that was conducted from March to April 2018 in the confines of the most recent medical college of the capital of the country. Only two batches ( $1^{\text {st }}$ year or second semester and $2^{\text {nd }}$ year or fourth semester) of medical students were present at that time and all efforts have been made to make them a part of the program and the study. A notice regarding the vaccination program was circulated among all the students of the medical college (only $1^{\text {st }}$ - and $2^{\text {nd }}$-year students are there) through proper channels of the department of community medicine. With a response rate of $81.3 \%$, a total of 161 students participated in the study out of 198 . The students were invited to the department on specified dates for awareness and immunization against hepatitis B. Before the distribution of the questionnaire, the objectives of the study were explained to the participants, and they were informed that their participation was voluntary. Each student turning up for the immunization sessions were given a self-administered, semi-structured, and pretested questionnaire which had attached consent form for immunization. The questionnaire, having 22 questions, is divided into four parts - sociodemographic details, knowledge about HBV, attitude toward HBV, and practices related to HBV. The students who had not received any hepatitis $B$ vaccine or had history of incomplete vaccination were enrolled for hepatitis B vaccination. Detailed methodology has been depicted in Figure 1.

The knowledge score, ranging from 0 to 16 , was calculated based on the correct responses out of the 16 knowledge questions. Similarly, the practice score, ranging from 0 to 4 , was calculated based on the responses that the student gave to four positive practices questions. KAPs were considered to be dependent variables and age, sex, and semester were considered as independent variables. Data were coded, entered, and analyzed using the Statistical Package for the Social Sciences. Ethical approval of this study was received from the Institutional Ethical Review Board of Dr. BSA Medical College. 


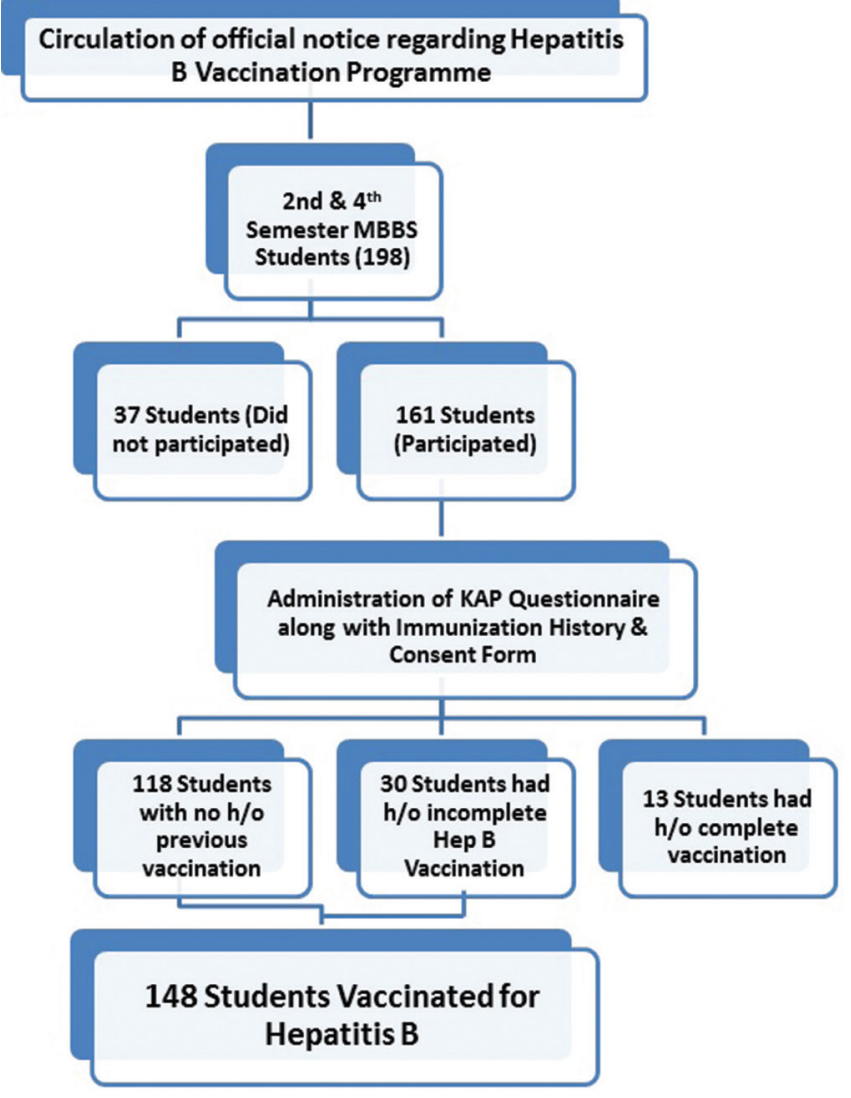

Figure 1: The flow chart of data collection and immunization activity. An official notice was circulated among the $2^{\text {nd }}$ - and $4^{\text {th }}$-semester medical students, whose total number was 198 . Out of them, 37 students did not participate in the study and 161 students did. The students who appeared were explained about the study and a knowledge, attitude, and practice questionnaire and consent form was distributed to them. Out of them, 13 students reported that they have received all three doses of hepatitis $B$ vaccine. Rest of the 148 students was vaccinated

\section{Results}

Characteristics of the study participants

From the combined strength of 198 of the second and fourth semester $\left(1^{\text {st }}\right.$ and $2^{\text {nd }}$ year) students, $161(81.3 \%)$ students turned up for immunization on the specified dates. The students were between the ages of 17 and 25 years. About 37 (18.7\%) students did not attend the sessions even after repeated announcements (at least three times) and their status could be ascertained. Majority of the students were male $(112,70 \%)$ as compared to females $(49,30 \%)$ [Table 1].

Knowledge of students regarding risk, mode of transmission, and prevention of hepatitis B

The knowledge about their risk of acquiring the disease at the hospital was present in less than half of the students. Only $50.3 \%$ were aware that it can be transmitted through percutaneous injury, 39.8\% knew about the transmission through contact of mucous membrane with potentially infectious material, and $44.1 \%$ knew that it can be transmitted if breached
Table 1: Descriptive characteristics of students involved in the study $(n=161)$

\begin{tabular}{lc}
\hline Characteristics & $\boldsymbol{n}(\%)$ \\
\hline Age (years) & \\
$17-18$ & $27(16.8)$ \\
$19-20$ & $95(59.0)$ \\
$21-22$ & $37(22.9)$ \\
$23-25$ & $2(1.2)$ \\
Sex & \\
Female & $49(30.4)$ \\
Male & $112(69.6)$ \\
Semester of MBBS & \\
Fourth & $73(45.3)$ \\
Second & $88(54.7)$ \\
\hline
\end{tabular}

skin comes in contact with infectious material. Only $47(29.2 \%)$ students knew that there is a $10 \%-30 \%$ risk of transmission of HBV infection in case of a needlestick injury. The mode of transmission or source of infection was correctly answered by $24 \%-94 \%$ of the students where maximum students ( $94.5 \%$ ) knew about the blood or blood products and very few students (24.2\%) knew about the breast milk as being the source of infection for hepatitis B. A large number of students knew about the ways of prevention of hepatitis B like $95.2 \%$ knew about use of sterile instruments, $92.5 \%$ about safe sex, $98 \%$ about hepatitis B vaccination, and $81.6 \%$ about use of gloves while handling infectious material. The mean knowledge score of $2^{\text {nd }}$-year students was 11.3 and that of $1^{\text {st }}$-year students was 10.6 out of 16 . There was statistically significant difference between the knowledge of $1^{\text {st }}$ and $2^{\text {nd }}$-year students $(P=0.008)$ [Table 2]. When the students were asked whether they have been exposed to potentially infectious material, everyone stated that they have not. Similarly, none of the students reported being hepatitis B status positive.

\section{Attitude of students toward vaccination against} hepatitis B

The attitude of the students has been given in Table 3 . Out of the four attitude questions, two were positive and two were negative. The attitude of the students was positive as $155(96.3 \%)$ opined that everyone should get hepatitis B vaccination and 145 (90.1\%) thought that the vaccine is certainly helpful. Only six (3.7\%) students said that they are either not at risk or do not need the vaccine.

Preventive practices of students toward hepatitis B Out of the 161 study participants, only $13(8 \%)$ students had received a completed course of hepatitis $B$ vaccination in the past, $30(18.7 \%)$ students had a history of inability to complete the three doses of hepatitis B vaccination and the rest $118(73.3 \%)$ students were never immunized against hepatitis B. Majority of the students stated that they ask for a new syringe whenever they get injections, they ask the barber to change the blade 
Table 2: The knowledge of medical students regarding the spread and prevention of hepatitis B infection

\begin{tabular}{|c|c|c|c|c|}
\hline Questions regarding knowledge of students & $2^{\text {nd }}$-year students (\%) & 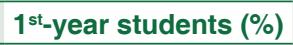 & Total students (\%) & $P$ \\
\hline \multicolumn{5}{|l|}{$\begin{array}{l}\text { 1. Are you at a risk of acquiring hepatitis B on exposure to any of } \\
\text { following? }\end{array}$} \\
\hline 1.1. Percutaneous injury (needlestick/cut with sharp object) & $47(64.4)$ & $34(38.6)$ & $81(50.3)$ & 0.001 \\
\hline $\begin{array}{l}\text { 1.2. Contact with mucous membrane with potentially infectious } \\
\text { material }\end{array}$ & $31(42.5)$ & $33(37.5)$ & $64(39.8)$ & 0.522 \\
\hline 1.3. Contact of breached skin with potentially infectious material & $40(54.8)$ & $31(35.2)$ & $71(44.1)$ & 0.013 \\
\hline \multicolumn{5}{|l|}{$\begin{array}{l}\text { 2. How much is the risk of HBV infection in case of prick } \\
\text { by needle/sharp object used in HBV-infected person, in } \\
\text { percentages? }\end{array}$} \\
\hline Correct response (10\%-30\%) & $24(32.9)$ & $23(26.1)$ & $47(29.2)$ & 0.349 \\
\hline \multicolumn{5}{|l|}{ 3. Which of the following can transmit Hepatitis B } \\
\hline 3.1. Contaminated blood and blood products & $68(93.2)$ & $84(95.5)$ & $152(94.4)$ & 0.526 \\
\hline 3.2. Using blades by the barber & $67(91.8)$ & $71(80.7)$ & $138(85.7)$ & 0.045 \\
\hline 3.3. Ear and nose piercing & $60(82.2)$ & $52(59.1)$ & $112(69.6)$ & 0.002 \\
\hline 3.4. Unsafe sex & $55(75.3)$ & $80(90.9)$ & $135(83.9)$ & 0.008 \\
\hline 3.5. From pregnant mother to child & $57(78.1)$ & $66(75.0)$ & $123(76.4)$ & 0.647 \\
\hline 3.6. Feces/urine of the patients & $39(53.4)$ & $40(45.5)$ & $79(49.1)$ & 0.314 \\
\hline 3.7. Breast milk of infected mother & $16(21.9)$ & $23(26.1)$ & $39(24.2)$ & 0.534 \\
\hline \multicolumn{5}{|l|}{ 4. Do you know Hepatitis B is preventable? } \\
\hline Yes & $67(91.8)$ & $80(90.9)$ & $147(91.3)$ & 0.845 \\
\hline \multicolumn{5}{|l|}{$\begin{array}{l}\text { 5. If the answer of question number } 7 \text { is yes, then how the } \\
\text { Hepatitis B can be prevented? }\end{array}$} \\
\hline 5.1. By using sterilized instruments & $64(95.5)$ & $76(95.0)$ & $140(95.2)$ & 0.882 \\
\hline 5.2. Practicing safe sex (use of condom) & $63(94.0)$ & $73(91.2)$ & $136(92.5)$ & 0.523 \\
\hline 5.3. By getting hepatitis $B$ vaccination & $66(98.5)$ & $78(97.5)$ & $144(98.0)$ & 0.667 \\
\hline 5.4. Using gloves while handling infectious material? & $61(91.0)$ & $59(73.8)$ & $120(81.6)$ & 0.007 \\
\hline Total knowledge score (mean) & 11.3 & 10.6 & 10.73 & 0.008 \\
\hline
\end{tabular}

$\mathrm{HBV}=$ Hepatitis B virus

Table 3: The attitude of students toward hepatitis B vaccination

\begin{tabular}{|c|c|c|c|c|}
\hline Questions pertaining to attitude & Fourth semester (\%) & Second semester (\%) & Total (\%) & $\boldsymbol{P}$ \\
\hline 1. Everyone should get HBV vaccination & $70(95.9)$ & $85(96.6)$ & $155(96.3)$ & 0.815 \\
\hline 2. I am not at risk, so do not need HBV vaccination & $2(2.7)$ & $4(4.5)$ & $6(3.7)$ & 0.547 \\
\hline 3. I am always careful; so do not need HBV vaccination & $1(1.4)$ & $5(5.7)$ & $6(3.7)$ & 0.150 \\
\hline 4. I think that HBV vaccine would certainly help & $67(91.8)$ & $78(88.6)$ & $145(90.1)$ & 0.507 \\
\hline
\end{tabular}

$\mathrm{HBV}=$ Hepatitis $\mathrm{B}$ virus

before shaving or cutting hair and they ask for sterilized equipment for ear or nose piercing $(89.4 \%, 89.4 \%$, and $88.8 \%$, respectively) [Table 4]. There was no difference in the attitude and practices of the medical students. However, there was a positive correlation between the knowledge scores and practice scores of the students $(P=0.012)$, implying that better knowledge of the disease has a positive effect on the practices exercised by an individual [Table 5].

\section{Discussion}

Exposure to bloodborne pathogens such as HBV infection remains a significant occupational hazard to HCWs, especially in countries where this infection is highly prevalent. ${ }^{[29]}$ KAP surveys form a useful tool to ascertain the problem, suggest solutions, and form policies. There is a paucity of data on KAP of medical students in the city, and this study has been done to throw some light on the same. The findings mandate a health awareness and hepatitis $B$ vaccination drive among medical colleges as the budding doctors are an invaluable resource and they should be provided with an armor of prevention against hepatitis B which is very likely to encounter them in their medical career.

From the study, it was found that majority of the medical students (59.6\%) had not received hepatitis B vaccination previously and $15.2 \%$ of them had incomplete vaccination. Status of $18.3 \%$ students could be ascertained as they did not turn up for vaccination. The reasons for nonparticipation could be lack of interest, fear of injection or adverse reaction, planning to get immunized later, or already received complete vaccination previously. Other studies have also reported low immunization rates among medical students. ${ }^{[30-32]}$ While one can easily assume that HCWs or medical students will show a high level of compliance with 
Table 4: Preventive practices of students toward Hepatitis B

\begin{tabular}{|c|c|c|c|c|}
\hline $\begin{array}{l}\text { Questions pertaining to practices of } \\
\text { students }\end{array}$ & Fourth semester ( $n=73), n(\%)$ & Second semester ( $n=88), n(\%)$ & Total $(n=161), n(\%)$ & $P$ \\
\hline \multicolumn{5}{|l|}{$\begin{array}{l}\text { 1. Have you received hepatitis B vaccine } \\
\text { previously }\end{array}$} \\
\hline Yes & $15(20.5)$ & $28(31.8)$ & $43(26.7)$ & 0.108 \\
\hline No & $58(79.5)$ & $60(68.2)$ & $118(73.3)$ & \\
\hline \multicolumn{5}{|l|}{$\begin{array}{l}\text { 2. If you needed injection, did you ask for a } \\
\text { new syringe before use? }\end{array}$} \\
\hline Yes & $67(91.8)$ & $77(87.5)$ & $144(89.4)$ & 0.379 \\
\hline No & $6(8.2)$ & $11(12.5)$ & $17(10.6)$ & \\
\hline \multicolumn{5}{|l|}{$\begin{array}{l}\text { 3. Do you ask your barber to use new } \\
\text { blade for shaving/hair cutting? }\end{array}$} \\
\hline Yes & $64(87.7)$ & $80(90.9)$ & $144(89.4)$ & 0.506 \\
\hline No & $9(12.3)$ & $8(9.1)$ & $17(10.6)$ & \\
\hline \multicolumn{5}{|l|}{$\begin{array}{l}\text { 4. Do you ask for sterilized equipment for } \\
\text { ear and nose piercing? }\end{array}$} \\
\hline Yes & $67(91.8)$ & $76(86.4)$ & $143(88.8)$ & 0.278 \\
\hline No & $6(8.2)$ & $12(13.6)$ & $18(11.2)$ & \\
\hline Total healthy practice score (mean) & 2.93 & 2.97 & 2.94 & 0.738 \\
\hline
\end{tabular}

Table 5: Correlation between knowledge score and healthy practice score

\begin{tabular}{lccccc}
\hline Scores & Mean & SD & $\boldsymbol{n}$ & Correlation coefficient & $\boldsymbol{P}$ \\
\hline $\begin{array}{l}\text { Total knowledge } \\
\text { score }\end{array}$ & 10.73 & 2.502 & 161 & 0.198 & 0.012 \\
$\begin{array}{l}\text { Total practice } \\
\text { score }\end{array}$ & 2.94 & 0.903 & 161 & & \\
\hline
\end{tabular}

SD = Standard deviation

regard to beneficial health procedures and program, evidence from literature suggests otherwise. ${ }^{[33-35]}$ The vaccination of HCWs become even more important as most of the HBV infections in HCWs are attributable to accidental percutaneous exposure which are deemed trivial to be recalled by HCWs for executing preventive measures. $^{[36]}$

The WHO seeks to achieve the goal of viral hepatitis elimination by 2030 and lack of general knowledge about viral hepatitis seems to be a barrier to reaching this goal. ${ }^{[37]}$ This study showed that medical students have poor knowledge and lack of awareness about hepatitis $\mathrm{B}$, its routes of transmission, risk factors, and modes of prevention; however, the attitude is largely positive. The findings are congruent with that of other studies. ${ }^{[24,38,39]}$ According to a study on medical students by Al-Ghamdi, anti-HBs levels were significantly low in many students after their primary immunization. Therefore, the testing medical students for anti-HBs levels may be warranted as they represent a high-risk population. ${ }^{[40]} \mathrm{A}$ few studies, however, reports good knowledge $(>80 \%)$ among the medical students. ${ }^{[25,29]}$

The study facilitated to immunize the future budding health-care professionals against hepatitis B infection. The study was planned and executed within the mandate of WHO hepatitis B guidelines in a low- and middle-income country such that maximum gains are attained by existing available resources. The immunization activity served as a good platform for the students for gaining awareness on related subtopics such as standard/universal precautions, biomedical waste management, and postexposure prophylaxis.

\section{Conclusion}

Newly enrolled students and other individuals attached to a high-risk setting such as a medical institution should be screened for immunization status during initial medical examination as the number of unimmunized persons, especially against hepatitis B, are high. The study served to screen and enroll individuals with incomplete or no immunization against hepatitis B and immunize them in the catch-up vaccination program. Such screening and catch-up vaccination program can enable policy-makers to achieve elimination levels of hepatitis B.

\section{Acknowledgments}

We would like to acknowledge the staff of the Department of Community Medicine, Dr. BSA Medical College and the study participants for their unreserved support during data collection.

\section{Financial support and sponsorship Nil.}

\section{Conflicts of interest}

There are no conflicts of interest.

\section{References}

1. Mühlemann B, Jones TC, Damgaard PB, Allentoft ME, Shevnina I, Logvin A, et al. Ancient hepatitis B viruses from the bronze age 
to the medieval period. Nature 2018;557:418-23.

2. Alter HJ, Blumberg BS. Further studies on a "new" human isoprecipitin system (Australia antigen). Blood 1966;27:297-309.

3. Gerlich WH. Medical virology of hepatitis B: How it began and where we are now. Virol J 2013;10:239.

4. Shepard CW, Simard EP, Finelli L, Fiore AE, Bell BP. Hepatitis $B$ virus infection: Epidemiology and vaccination. Epidemiol Rev 2006;28:112-25.

5. World Health Organization. World Health Organization Hepatitis B.htm. Geneva: World Health Organization. Available from: http:/ / www.whohepatitisB.htm. [Last accessed on 2018 Jul 10].

6. Thio CL. Hepatitis B and human immunodeficiency virus coinfection. Hepatology 2009;49:S138-45.

7. Puri P. Tackling the hepatitis B disease burden in India. J Clin Exp Hepatol 2014;4:312-9.

8. World Health Organization. Hepatitis B: WHO/CDS/CSR/ LYO/2002.2. World Health Organization. Available from: http:/ / www.who.int/csr/disease/hepatitis/whocdscsrlyo20022/en/ print.html. [Last accessed on $2018 \mathrm{Jul}$ 09].

9. Gupta S, Gupta R, Joshi YK, Singh S. Role of horizontal transmission in hepatitis B virus spread among household contacts in North India. Intervirology 2008;51:7-13.

10. Singhal V, Bora D, Singh S. Hepatitis B in health care workers: Indian scenario. J Lab Physicians 2009;1:41-8.

11. Hadler SC. Hepatitis B virus infection and health care workers. Vaccine 1990;8 Suppl 1:S24-8.

12. Arora NK. Injection practices in India. WHO South East Asia J Public Health 2012;1:189-200.

13. Murhekar MV, Rao RC, Ghosal SR, Sehgal SC. Assessment of injection-related practices in a tribal community of Andaman and Nicobar Islands, India. Public Health 2005;119:655-8.

14. Rajasekaran M, Sivagnanam G, Thirumalaikolundusubramainan $P$, Namasivayam K, Ravindranath C. Injection practices in Southern part of India. Public Health 2003;117:208-13.

15. Rathi A, Kumar V, Majhi J, Jain S, Lal P, Singh SV. Incidence of occupational exposures in a tertiary health care center. Indian J Sex Transm Dis AIDS 2012;33:91-7.

16. Prüss-Ustün A, Rapiti E, Hutin Y. Estimation of the global burden of disease attributable to contaminated sharps injuries among health-care workers. Am J Ind Med 2005;48:482-90.

17. Taneja N, Biswal M. Safe disposal of infectious waste - Indian perspective. J Hosp Infect 2006;62:525-7.

18. Rogers B, Goodno L. Evaluation of interventions to prevent needlestick injuries in health care occupations. Am J Prev Med 2000;18:90-8.

19. Kohn WG, Collins AS, Cleveland JL, Harte JA, Eklund KJ, Malvitz DM, et al. Guidelines for infection control in dental health-care settings-2003. MMWR Recomm Rep 2003;52:1-61.

20. Rachiotis G, Goritsas C, Alikakou V, Ferti A, Roumeliotou A. Vaccination against hepatitis $B$ virus in workers of a general hospital in Athens. Med Lav 2005;96:80-6.

21. Molinari JA. Infection control: Its evolution to the current standard precautions. J Am Dent Assoc 2003;134:569-74.

22. World Health Organization. Health Care Worker Safety. Available from: http://www.who.int/occupational_health/ activities/1am_hcw.pdf. [Last accessed on 2018 Jul 10].

23. Hutin Y, Hauri A, Chiarello L, Catlin M, Stilwell B, Ghebrehiwet T, et al. Best infection control practices for intradermal, subcutaneous, and intramuscular needle injections. Bull World Health Organ 2003;81:491-500.

24. Pathoumthong K, Khampanisong P, Quet F, Latthaphasavang V, Souvong V, Buisson Y, et al. Vaccination status, knowledge and awareness towards hepatitis B among students of health professions in Vientiane, Lao PDR. Vaccine 2014;32:4993-9.

25. Noubiap JJ, Nansseu JR, Kengne KK, Tchokfe Ndoula S, Agyingi LA. Occupational exposure to blood, hepatitis B vaccine knowledge and uptake among medical students in Cameroon. BMC Med Educ 2013;13:148.

26. Lahariya C, Subramanya BP, Sosler S. An assessment of hepatitis B vaccine introduction in India: Lessons for roll out and scale up of new vaccines in immunization programs. Indian J Public Health 2013;57:8-14.

27. World Health Organization. Guidelines for the Prevention Care and Treatment of Persons with Chronic Hepatitis B Infection: Mar-15. Geneva: World Health Organization; 5 August, 2015.

28. World Health Organization. Global Health Sector Strategy on Viral Hepatitis 2016-2021: Towards Ending Viral Hepatitis. Geneva: World Health Organization; June, 2016.

29. Abdela A, Woldu B, Haile K, Mathewos B, Deressa T. Assessment of knowledge, attitudes and practices toward prevention of hepatitis B virus infection among students of medicine and health sciences in Northwest Ethiopia. BMC Res Notes 2016;9:410.

30. Paul N, Peterside O. Hepatitis B vaccination rate among medical students at the university of Port Harcourt teaching hospital (UPTH). World J Vaccines 2015;5:1-7.

31. Giri MR, Panda JK, Sahoo AK. Hepatitis B awareness and vaccination status among first year medical students. Int J Community Med Public Health 2016;3,2:530-2.

32. Vinodhkumaradithyaa A, Srinivasan M, Sankarasubramanian R, Uma A, Ananthalakshmi I, Thirumalaikolundusubramanian P, et al. Hepatitis B vaccination among medical students. Indian J Community Med 2008;33:67-8.

33. Dancocks A, Hewitt S. Hepatitis B immunisation status of A\&E healthcare workers. Occup Health (Lond) 1994;46:20, 22-3.

34. Echavez MI, Shaw FE Jr., Scarlett MI, Kane MA. Hepatitis B vaccine usage among dental practitioners in the United States: An epidemiological survey. J Public Health Dent 1987;47:182-5.

35. Harward MP, Kaiser DL, Fedson DS. Acceptance of hepatitis $B$ vaccine by medical and surgical residents. J Gen Intern Med 1988;3:150-5.

36. U.S. Public Health Service. Updated U.S. Public Health Service guidelines for the management of occupational exposures to $\mathrm{HBV}, \mathrm{HCV}$, and HIV and recommendations for postexposure prophylaxis. MMWR Recomm Rep 2001;50:1-52.

37. Karimi-Sari H, Bayatpoor ME, Aftabi Khotbesara M, Ebrahimi MS, Sattari Z, Sattari P, et al. Knowledge, attitude, and practice of Iranian health sciences students regarding hepatitis $B$ and $C$ virus infections: A national survey. Am J Infect Control 2017;45:e135-41.

38. Mesfin YM, Kibret KT. Assessment of knowledge and practice towards hepatitis B among medical and health science students in Haramaya University, Ethiopia. PLoS One 2013;8:e79642.

39. Othman SM, Saleh AM, Shabila NP. Knowledge about hepatitis B infection among medical students in Erbil city, Iraq. Eur Sci J 2013;3:1857-7881.

40. Al Ghamdi SS, Fallatah HI, Fetyani DM, Al-Mughales JA, Gelaidan AT. Long-term efficacy of the hepatitis B vaccine in a high-risk group. J Med Virol 2013;85:1518-22. 